\title{
WADAH AKTIVITAS DAN KOMUNITAS PESISIR DI MUARA BARU
}

\author{
Febi Claudia Lie ${ }^{1)}$, Lina Purnama ${ }^{2)}$ \\ 1) Program Studi S1 Arsitektur, Fakultas Teknik, Universitas Tarumanagara, febiclie@gmail.com \\ 2) Program Studi S1 Arsitektur, Fakultas Teknik, Universitas Tarumanagara, linapurnama.112@gmail.com \\ Masuk: 10-01-2020, revisi: 28-01-2020, diterima untuk diterbitkan: 09-05-2020 (doi: 10.24912/stupa.v2i1.6865)
}

\begin{abstract}
Abstrak
Pembangunan kota Jakarta awalnya dimulai dari area pinggir laut yang kemudian semakin berkembang ke pusat kota, seiring berlangsungnya pembangunan di pusat kota, daerah pinggir/pesisir mulai ditinggalkan dan tidak tersentuh. Pengembangan kota Jakarta yang hanya berorientasi pada kepentingan kapitalis juga mengakibatkan kurangnya ruang publik bagi masyarakat, sehingga mengakibatkan masyarakat mengatasinya secara mandiri. Jalanjalan di dalam perumahan hingga perkampungan yang difungsikan oleh warga setempat sebagai ruang untuk bersosialisasi dengan tetangga atau tempat melakukan aktivitas. Kawasan Muara Baru yang terletak di wilayah pesisir Jakarta bagian Utara, masih terdapat banyak area perkampungan, tetapi tidak difasilitasi oleh ruang publik atau ruang terbuka sehingga untuk melakukan kegiatan berinteraksi dan beraktivitas, dilakukan di jalan/lorong kecil didepan rumah, yang dapat mengganggu lalu lintas dan juga membahayakan keselamatan warga dan juga pengguna jalan. Fenomena ini menandakan bahwa kebutuhan masyarakat akan ruang publik sangat tinggi dan perlu segera diantisipasi agar tidak terjadi degradasi lingkungan dan sosial, sehingga tujuan dari proyek ini adalah sebagai linkage yang menggabungkan manusia dengan lingkungan di sekitarnya, serta manusia dengan manusia lainnya, selain itu juga untuk membantu perekonomian dan usaha industri rumahan, yang dapat dilakukan serta menghasilkan uang untuk membantu perekonomian warga, serta menimbulkan interaksi positif, seperti pertukaran ilmu dan pembangunan aspek ekonomi, yang ke depannya akan menghasilkan kemajuan pada kota Jakarta dengan aspek sosial dan ekonomi yang seimbang.
\end{abstract}

Kata kunci: Muara Baru; ruang public; Third place

\begin{abstract}
Jakarta was developed started from the coastline and gradually moved to the centre of the city which left the coastal area remain untouch. The development of Jakarta which only oriented on capitalism cause in a lack of public space for the community, which make public coping with the issues independently. The roads in the housing area and villages was used by local residents as a space to socialize with neighbors or a place to do activities. There are still lots of kampung remained in Muara Baru which located in North Jakarta, but not facilitated by public space and open space to accommodate the citizen's need to socialize and do their activity, so they carried out those activities in the middle of the road or alley which can disturb the traffic and endangered other people's lives. This phenomenon indicates that the community's need for public space is very high and needs to be anticipated immediately in order to avoid environmental and social degradation. The purpose of this project is to become a linkage that connect people with the surrounding environment, as well as humans with other humans, while this project also help the economy and home industry businesses, which bring in money to help the economy of local citizens, and cause positive interactions, such as knowledge exchange and development in economic aspects.
\end{abstract}

\section{Keywords: Muara Baru; public space; Third place}




\section{PENDAHULUAN}

Sebagai makhluk sosial, kehidupan manusia selalu ada keterikatan dengan lingkungan sebagai tempat manusia beraktifitas. Manusia membutuhkan kehadiran orang lain untuk melengkapi kehidupannya dan juga membutuhkan wadah untuk melakukan aktivitas tersebut. Kebutuhan inilah yang kemudian inilah yang kemudian melatarbelakangi terbentuknya ruang publik. Ruang publik (public space) didefinisikan sebagai ruang/tempat dimana setiap orang dapat bebas keluar masuk tanpa dipungut suatu bayaran. Contohnya adalah jalan dan taman umum dimana setiap orang bebas memasuki dan menggunakannya. Karena bersifat bisa digunakan atau dimasuki setiap orang, ruang publik tidak mempertimbangkan aspek privasi bagi penggunanya.

Ruang publik memberikan warna sendiri dalam kehidupan masyarakat, ruang ini dibutuhkan sebagai respon terhadap ruang-ruang rutin dalam kehidupan masyarakat seperti tempat tinggal dan tempat bekerja. Di ruang publik inilah terjadi pertukaran dan pergerakan energi yang menggerakan dan menghidupkan kawasan/lingkungan tersebut. Bentuk ruang publik yang ada, merupakan gambaran nyata dari nilai-nilai kehidupan publik - privat yang dianut komunitas tersebut. Munculnya ruang publik juga merupakan respon usaha masyarakat untuk memenuhi kebutuhannya sendiri, pasar sebagai tempat bertransaksi dan memenuhi kebutuhan hidup, gedung untuk perayaan dan festival dan lain sebagainya. Sedangkan di kota Jakarta, yang merupakan rumah bagi \pm 10 juta jiwa masyarakat masih minim ruang untuk bersosialisasi sehingga masyarakat berusaha mengatasi hal ini secara mandiri yaitu seperti mengalihfungsikan fasilitas lain sebagai tempat bersosialisasi. Sehingga pembangunan sebuah ruang publik seperti Third place sangat dibutuhkan sebagai tempat bersosialisasi.

\section{KAJIAN LITERATUR}

\section{Third place}

Konsep Third place dikemukakan oleh Ray Oldenburg (1999) sebagai pembentuk ruang interaksi sosial. Pengertiaan Third place menurut Oldenburg menyatakan bahwa Third place merupakan tempat untuk orang yang ingin mengobati stress, kesepian, dan keterasingan. Pengertian dari Third place adalah suatu tempat yang bisa dijadikan tempat berlindung sementara dari kebosanan. Tidak hanya dijadikan tempat untuk melarikan diri, tetapi di mana orang dapat bersantai dan merasa terhibur dan juga mendapatkan ketenangan di dalamnya. Pada Third place orang melarikan diri dari First place (rumah) dan second place (tempat kerja atau sekolah) untuk membuka jati dirinya dan bertujuan untuk bersosialisasi di dalamnya.

Menurut Ray Oldenburg dalam buku The Great Good Place, dijelaskan bahwa ada 7 karakteristik Third place, yaitu: Netral Adanya tempat yang bersifat netral dimana semua orang merasa seperti di rumah dan nyaman karena hubungan dapat terjalin lebih intim jika merasa nyaman pada suatu lingkungan.

\section{Kesamarataan}

Tempat yang menyamaratakan adalah tempat yang dapat diakses oleh masyarakat umum tanpa terkecuali, serta terjadi kesempatan bersosialisasi dimana orang berkumpul untuk tujuan mencari kegembiraan yang melibatkan kepribadian mereka di luar konteks tujuan, tugas, atau peran. Pengunjung yang datang meninggalkan semua atribut keseharian mereka seperti jabatan, latar belakang budaya, dll.

\section{Komunikasi}

Third place sebagai tempat pertemuan didominasi dengan aktivitas perbincangan. Topik yang diperbincangan bermacam-macam, kebanyakkan tentang politik maupun ekonomi.

\section{Aksesbilitas dan akomodasi}

Third place memberikan layanan terbaik dan terlengkap di mana seseorang dapat pergi sendiri 
hampir setiap saat, siang atau malam hari. Akses ke Third place harus mudah untuk dikunjungi. Jam operasional Third place dapat diakses saat siang dan malam hari.

Reguler Pengunjung Third place adalah pengunjung reguler, hal ini terjadi karena Third place merupakan bagian dari komunitas suatu lingkungan atau area (district). Kedekatan dan interaksi antar pengunjung merupakan hal terpenting dalam pembentukkan Third place, sehingga hal ini kemudian tercermin dalam pembentukkan Third place. Pengunjung reguler inilah yang dapat mempermudah komunikasi dalam komunitas.

\section{A low profile}

Third place biasanya bersifat sederhana, tidak menarik banyak orang asing atau pengunjung sementara. Kesederhaan dapat dilihat dari desain ruangan yang tidak menginterpretasikan tingkat sosial.

\section{The Mood Is Playful}

Suasana yang tepat untuk Third place adalah suasana menyenangkan, sehingga ketika meninggalkan Third place, orang keluar dengan muka tersenyum dan kembali ke rumah dengan perasaan gembira. Third place tidak hanya menjadi tempat untuk suatu masyarakat berkumpul melainkan tempat di mana masyarakat dapat menemukan kegembiraan dalam kebersamaan. Suasana yang menyenangkan dapat mendorong orang untuk mengunjungi Third place berulangulang.

\section{A Home Away From Home}

Terdapat perbedaan antara rumah dengan Third place. Rumah memiliki aturan pribadi sedangkan Third place tidak. Rumah menyediakan lebih banyak kegiatan dibandingkan dengan Third place. Third place harus bisa menjadi rumah bagi pengunjungnya.

\section{Social Place}

Manusia sebagai makhluk sosial selalu berinteraksi dengan cara memilih siapa dan apa serta tujuan mereka berinteraksi. Kondisi ini kemudian menyebabkan terbentuknya suatu masyarakat atau disebut dengan komunitas. Pembentukkan komunitas sangat dinamis, baik dari segi jumlah manusianya maupun dari tujuan interaksinya. Anggota dari komunitas ini dapat berganti-ganti kemudian membentuk komunitas baru. Keberadaan komunitas ini kemudian membentuk social space atau ruang sosial.

Sosial space memiliki faktor terpenting yaitu berkumpul. Ketika berkumpul, setiap individu dapat saling bertemu, bertukar pikiran, mengeluarkan pendapat, belajar, bermain dan sebagainya. Kegiatan seperti ini akan menimbulkan ikatan berdasarkan sesuatu yang disukainya, namun dalam masyarakat modern, yang sangat individual, diperlukan suatu event atau program yang mampu menghubungkan satu dengan lainnya. Setiap ikatan memiliki kekhasan tersendiri, seperti faktor usia, pada remaja lebih mudah terjadi ikatan sosial daripada anak-anak atau dewasa. Ikatannya dapat dibentuk melalui grup belajar (non formal) maupun permainan tertentu. Sedangkan usia dewasa lebih terkait dengan isu-isu tertentu yang menyebabkan mereka saling bertemu. Faktor gender juga menentukan, wanita lebih mudah membentuk ikatan sosial daripada pria. Kegiatan-kegiatan seperti arisan, kursus masak, child care dapat mempertemukan pengunjung satu dengan lainnya dan kemudian membentuk ikatan sosial. Ikatan-ikatan sosial ini kemudian akan membentuk komunitaskomunitas yang perlu diakomodir di sebuah tempat. Ikatan sosial dapat terjadi bila bersifat terus menerus. Semakin lama ikatan itu akan semakin kuat, karena itu diperlukan tempat yang dapat membantu setiap individu membentuk ikatan itu. 


\section{Open Architecture as Third place}

Sebuah Third place perlu terbuka bagi siapa saja tanpa melihat latar belakang masing individu maupun komunitasnya. Namun, keterbukaan ini tetap perlu hidup dalam sebuah konteks sosial, yaitu konteks sosial masyarakat kota termasuk dengan keragamannya. Third place sebagai tempat yang mampu mengakomodir kebutuhan kota diharapkan mampu berfungsi secara fleksible dan juga dinamis menurut irama masyarakatnya. Pemilihan struktur pun menjadi penting, dikarenakan keperlun untuk menyambung dan menghubungkan antar program sehingga setiap program dapat saling mengisi dan beroperasi dengan tanpa hambatan. Pemilihan struktur ini diharapkan juga dapat mengartikulasikan komunitas yang tergabung didalamnya, karena itu struktur perlu dibuat secara terbuka. Keterbukaan memiliki peran penting agar setiap program memiliki kesempatan yang sama.

Open architecture merupakan sistem yang terbuka dan mampu beradaptasi dengan kepentingan terpilih. Konflik - konflik yang terjadi di dalam masyarakat kota dapat dipecahkan dengan melakukan pendekatan desain (design approach) dan juga strategi perancangan. Open Architecture merupakan sebuah perkembangan dalam dunia arsitektur dimana program "space" tidak lagi sesuai tipologi, melainkan ada penambahan program lain menjadi sebuah "place" tanpa menghilangkan program / fungsi utama dari space tersebut. Kedua objek tersebut kemudian membentuk objek arsitektur yang disebut the Third place.

Open Architecture menjadi kesempatan untuk menciptakan sebuah platform arsitektur yang dapat dikombinasikan dengan berbagai macam keadaan dan kondisi masyarakat. Open architecture sebagai platform akan dibuat berdasarkan salah satu dari 3 kategori yaitu kategori commercial, hospitality, dan entertainment.

Commercial: kategori yang terkait dengan hal - hal jual beli baik jasa maupun barang dan hal hal lain yang mendukung jual beli. Hospitality: hal - hal yang terkait penerimaan tamu, pengunjung dan juga pelayanan terhadap masyarakat. Entertainment: terkait dengan ekspresi, karena itu erat kaitannya dengan seni dan budaya, yang juga memiliki kaitan dengan edukasi.

\section{METODE}

Analisis Sintesis Pada proses perancangan Wadah Aktivitas dan Komunitas Pesisir di Muara Baru, metode yang digunakan adalah metode analisis sintesis. Dalam metode Analisis Sintesis perancangan dilakukan secara sadar dan diuji kemampuannya dalam hal menguraikan dan menggabungkan kembali suatu konteks untuk menghasilkan form / bentuk. Pengertian bentuk disini adalah diagram hasil kerjasama yang menentukan arah akhir sebuah proses. Bentuk diagram dalam kaitan ini adalah sebuah penyelesaian. Penyelesaian terjadi apabila konflikkonflik yang terdapat dalam konteks desain telah terselesaikan. Tanda-tanda bahwa suatu masalah peranangan telah diselesaikan adalah terciptanya kecocokan ( fit) antara bentuk dan konteks. Keadaan sebaliknya adalah misfit, yaitu bentuk dan konteks tidak saling mengisi.

Untuk mencapai fit inilah kita perlu memperhitungkan semua unsur dengan hubunganhubungannya dalam suatu sistem proses. Suatu sistem mengandung subsistem yang bekerja sama satu dengan lainnya namun dalam dirinya cukup bebas. Proses penyelesaian dalam hal ini adalah bagaikan kegiatan serangkaian subsistem yang saling terkait mencari jalan perbaikan atau adaptasi. Hubungan antara sistem dan subsistem ada yang amat kuat sehingga terjadi saling ketergantungan, dan ada yang tidak terlalu kuat. Proses perbaikan itu berlangsung dalam kurun waktu tertentu, sehingga setiap siklus perbaikan dan perbaikan ulang yang muncul saat adaptasi dapat kita batasi dalam satu subsistem. Dalam Metode Analisis - Sintesis akan terjadi proses menggabungkan dan menguraikan kembali. Konteks yang ada dikumpulkan dan diklasifikasikan, lalu digabungkan sesuai kecocokannya, ataupun sebaliknya. Proses penggabungan adalah sintesis, dan proses penguraian adalah analisis. Bila analisis menelusuri masalah, maka sintesis menghasilkan bentuk. 


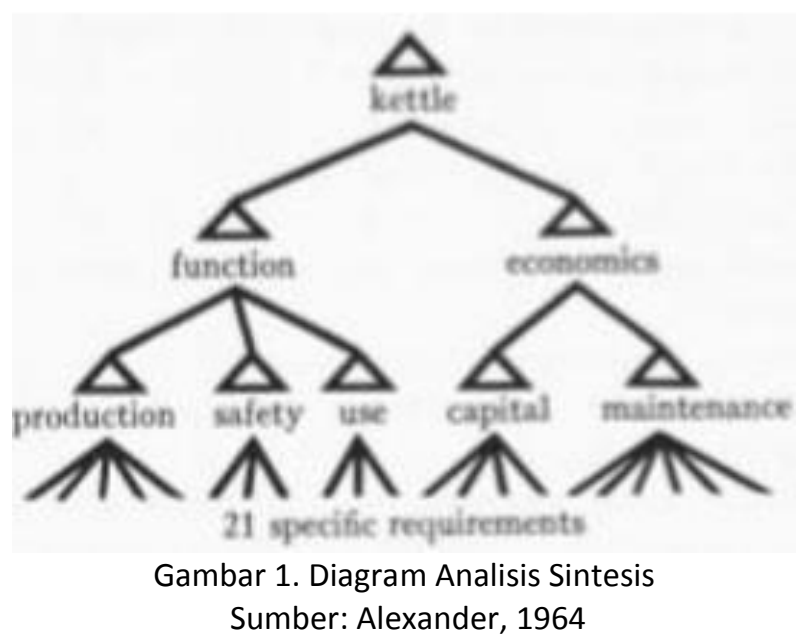

Cara berpikir diatas mengandung terlalu banyak kemungkinan, sehingga konteks yang menentukan perancangan di sekitar kita kini amat kompleks, tidak seperti konteks di lingkungan yang sederhana. Dalam lingkungan tradisional, masyarakat merancang secara tidak sadar diri (unselfconscious). Sedangkan dalam lingkungan masyarakat modern, masyarakat keadaan merancang dengan sadar diri (selfconscious). Hal ini dilakukan apabila unselfconscious sudah tidak dapat menyelesaikan masalah.

Dalam Perancangan, masalah tidak diselesaikan langsung di tempat karena konteks yang rumit, namun konteks tetap diperhatikan secara nyata secara konseptual. Konseptual akan menimbulkan interaksi dan pada kenyatannya akan selalu terjadi kesalahan, dapat diakibatkan oleh rasa tidak puas, perancangan dirasa belum fit dengan baik. Maka diperlukan gambarangambaran abstrak yang lebih jauh lagi, juga untuk menghapuskan kecenderungan pribadi perancang. Masalah perancangan berbeda dari adanya upaya mencapai kecocokan antara kebenaran bentuk dan konteks. Kecocokan terjadi jika ditemukan kekompakan dan koherensi internal.

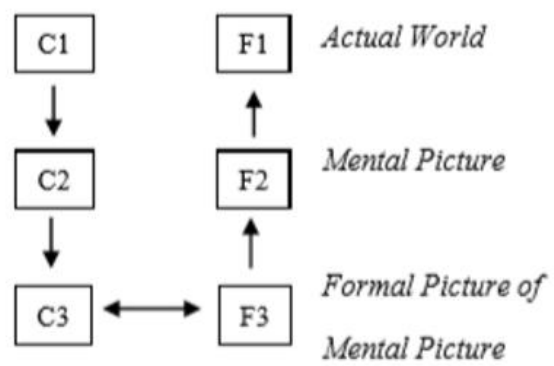

Gambar 2. Improvementof Selfconscious Situation Sumber: Alexander, 1964

Form tercipta dari tata olah pola-pola atau diagram. Pada pola terdapat pengulangan keteraturan. Pada diagram pola abstrak hubungan ragawi yang menentukan suatu system kekuatan dan antar tindak ang berbenturan dan dapat terbentuk secara mandiri. Diagram pada umumnya harus bisa dibaca dan memudahkan suatu pengerjaan.

Hal pertama yang dilakukan adalah mengamati secara individual bagaimana kehidupan masyarakat secara umum. Bagaimana mereka berinteraksi, bagaimana mereka tinggal dan menyelesaikan permasalahan. Artinya tahap awal sebelum memulai perancangan adalah tahap riset dan survey, selanjutnya dilanjutkan dengan pengolahan data dan perancangan dengan 
metode Analisis dan Sintesis

Tabel 1. Metode Analisis - Sintesis

\begin{tabular}{|c|c|c|}
\hline Riset / Survey & Analisis & Sintesis \\
\hline \multirow{2}{*}{$\begin{array}{l}\text { Melakukan pencarian data } \\
\text { primer sekunder (buku, } \\
\text { internet, dan berita) }\end{array}$} & Analisis kawasan dan tapak & \multirow[b]{2}{*}{$\begin{array}{l}\text { Merencanakan scenario } \\
\text { aktifitas }\end{array}$} \\
\hline & $\begin{array}{l}\text { Analisis kajian teori yang } \\
\text { disesuaikan dengan isu, } \\
\text { masalah dan potensi. }\end{array}$ & \\
\hline \multirow{2}{*}{$\begin{array}{l}\text { Membuat Kajian Teori sesuai } \\
\text { dengan konteks (mengenai } \\
\text { third place, open architecture, } \\
\text { social space, dan gangguan } \\
\text { mental). }\end{array}$} & $\begin{array}{l}\text { Menjabarkan segala konteks } \\
\text { yang berhubungan dengan } \\
\text { tujuan proyek. }\end{array}$ & \multirow{2}{*}{ Membuat Storyboarding } \\
\hline & $\begin{array}{l}\text { Menemukan tipe arsitektur } \\
\text { yang berhubungan dengan } \\
\text { tujuan proyek. }\end{array}$ & \\
\hline
\end{tabular}

iumber: Penulis, 2019

Pada bagian Metode, penulis perlu menjabarkan data yang akan dikumpulkan selama proses penelitian/ desain dan selanjutnya secara rinci dan runut menjelaskan metode pengumpulan data, tahapan penelitian/ desain, metode analisis dan sintesis data hingga menghasilkan pernyataan kesimpulan. Jika penulis menggunakan alat penelitian atau simulasi desain yang spesifik, maka perlu dicantumkan juga dalam bagian ini. Apabila metode yang digunakan berasal dari beberapa sumber, maka penulis perlu menjelaskan kajian terkait metode tersebut secara jelas dengan menyertakan sumber asli. Penulis diharapkan memaparkan secara detail alasan dalam menggunakan suatu metode tertentu.

\section{DISKUSI DAN HASIL}

Proyek ini dinamakan sebagai Wadah Aktivitas dan Komunitas Pesisir di Muara Baru dengan konsep dasar Third place yang berisi program yang mendukung aktivitas pembangunan komunitas yang biasanya dilakukan oleh "The Great Good Place". Wadah Aktivitas dan Komunitas Pesisir di Muara Baru ini berisi program yang mendukung komunitas nelayan yang ada di kawasan Muara Baru dan untuk mempererat hubungan angar warga serta menjadikan bangunan ini linkage yang menggabungkan manusia dengan lingkungan di sekitarnya, serta manusia dengan manusia lainnya, sebagai bentuk kontribusi proyek terhadap kota.

Komunitas Pesisir di Muara Baru ini berisi program yang mendukung komunitas nelayan yang ada di kawasan Muara Baru dan untuk mempererat hubungan angar warga serta menjadikan bangunan ini linkage yang menggabungkan manusia dengan lingkungan di sekitarnya, serta manusia dengan manusia lainnya, sebagai bentuk kontribusi proyek terhadap kota. 


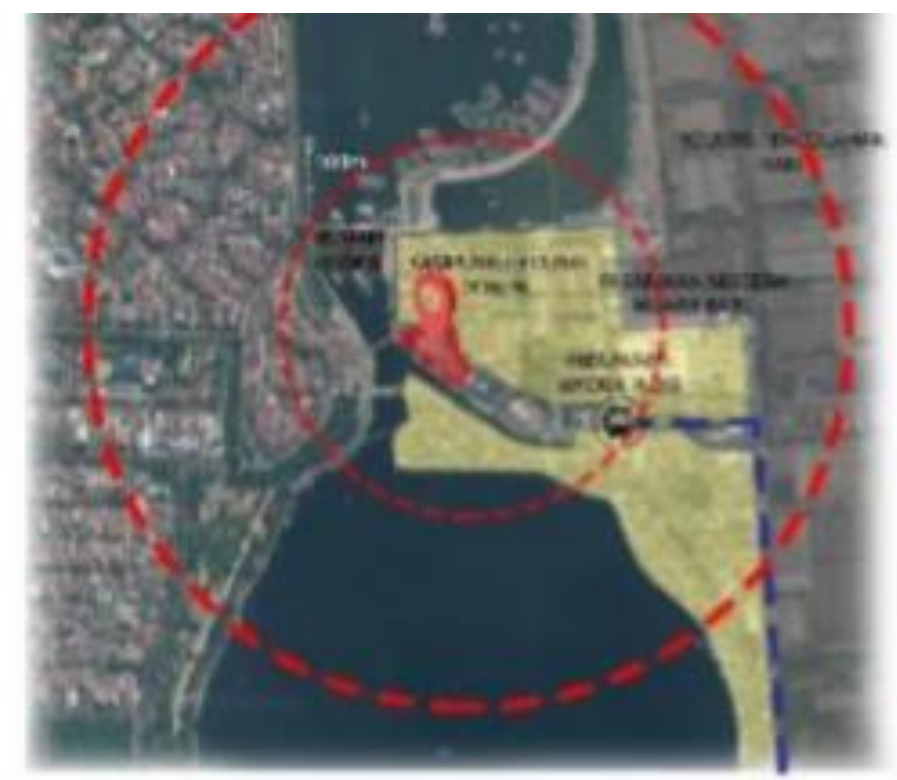

Gambar 3. Lokasi Tapak

Sumber:Penulis, 2019

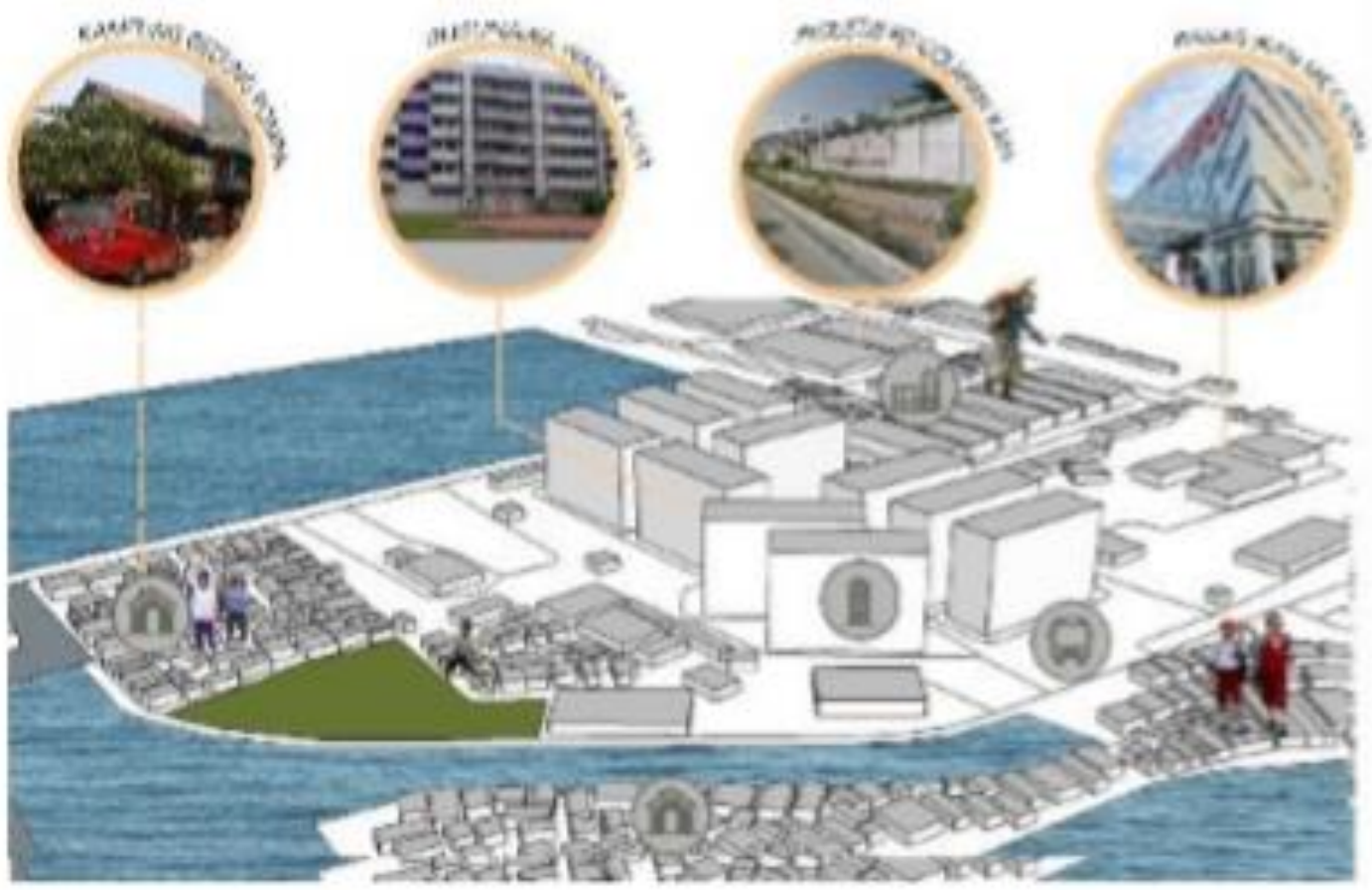

Gambar 4. Aktivitas disekitar tapak

Sumber:Penulis, 2019

Berdasarkan gambar di atas, proyek ini berada di Jl. Muara Baru Ujung Gedung Pompa bersebelahan langsung dengan Kampung Gedung Pompa dan Rusun Waduk Pluit (1st Place) yang mayoritas masyarakatnya bekerja di pelabuhan, pasar ikan dan daerah industri perikanan (2nd place). Pergerakan mobilitas pedestrian di jalan utama (Jl. Muara Baru Ujung Gedung Pompa) tidak terlalu ramai, sedangkan di jalan kolektor yang merupakan jalanan di kampung sangat ramai karena dipenuhi oleh aktivitas masyarakat disekitarnya sehingga mengganggu aktivitas lalu lintas disana dan juga membahayakan keselamatan warga dan juga pengguna jalan. Site memiliki peraturan pemerintah yaitu memiliki luas tapak $6.000 \mathrm{~m} 2$ dengan besaran proyek 
sekitar $9.600 \mathrm{~m} 2$. Memiliki tinggi bangunan maksimal 4 lantai dengan peruntukan perkantoran, perdagangan dan jasa. Daerah hijau sebesar $1.800 \mathrm{~m} 2$ (KDH 30\%), luas dasar bangunan maksimal sebesar $2.400 \mathrm{~m} 2$ (KDB 40\%)

Tapak dipilih karena melihat analisis potensi yang ada. Tapak berada pada lokasi yang dekat dengan pemukiman (1st place) dan juga tempat kerja (2nd place) dimana hal ini merupakan salah satu syarat Third place, yang dekat dengan rumah dan tempat kerja. Selain itu, di kawasan ini kekurangan ruang publik, dan belum ada proyek serupa.

Program

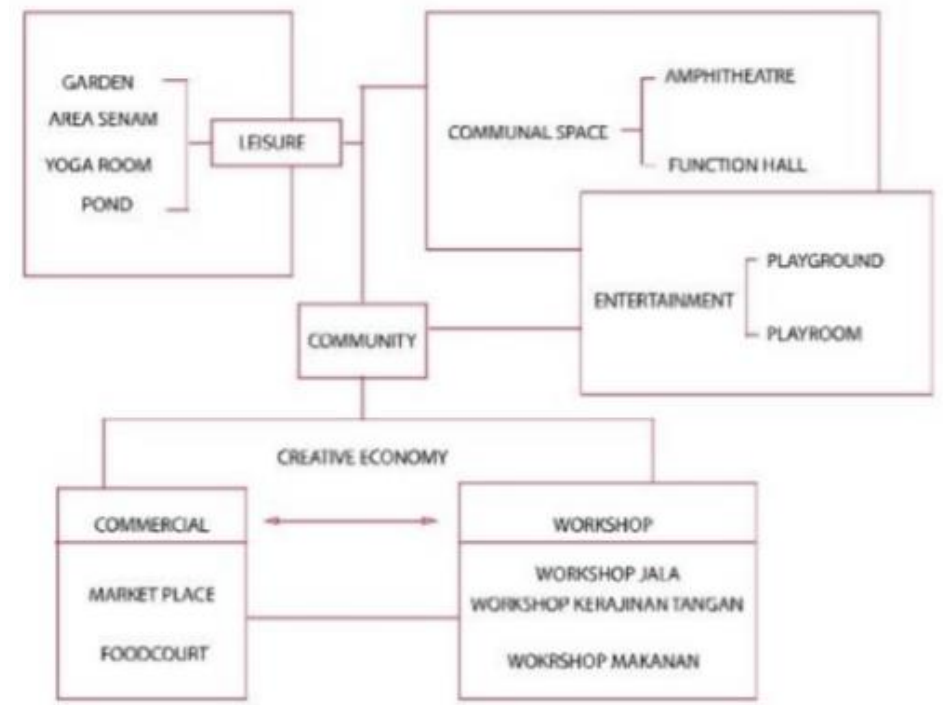

Gambar 5. Diagram Programatik Peletakan Program pada Bangunan Sumber:Penulis, 2019

Berdasarkan gambar diatas, program pada proyek ini terdiri dari 5 program utama yang dibagi lagi menjadi dua jenis program yaitu, tiga program utama yang merupakan hasil implementasi dari konsep Third place, dan 2 program lainnya hasil analisis sintesis berdasarkan kegiatan / aktivitas masyarakat setempat. Tiga program utama dari proyek ini adalah leisure, communal space dan entertainment. Untuk program leisure terdapat area hijau berupa taman, area senam dan area yoga untuk menunjang kualitas hidup masyarakat setempat. Untuk area komunal, terdapat area amphitheatre dan multifunction hall, sebagai tempat berkumpul dan berlangsungnya acara di dalam proyek ini, untuk area hiburan / entertainment, terdapat program taman bermain. Sedangkan untuk program yang berdasarkan hasil analisis aktivitas masyarakat adalah program workshop, dimana warga disekitar tapak mayoritas merupakan nelayan dan buruh pabrik serta perkumpulan ibu-ibu PKK yang apabila hasil kegiatannya dikembangkan dapat membantu perekonomian keluarga dan juga memberi citra pada kawasan Muara Baru, sehingga penyediaan ruang workshop ini dapat mewadahi aktivitas tersebut agar berlangsung dengan lebih maksimal. Program workshop ini berkaitan dengan program komersil dan gallery dimana hasil workshop dapat diperjualbelikan atau dipajang di area galeri.

\section{Gubahan massa \& penempatan program}

Pembentukan gubahan massa dimulai dari akses masuk pedestrian, sesuai salah satu syarat Third place yaitu aksesibilitas, kemudian akses masuk tersebut disambung dan membentuk jalan didalam tapak yang membagi tapak menjadi 3 bagian, kemudian massa dibentuk sesuai bentuk tapak. Untuk memenuhi kebutuhan ruang pada program, massa serupa ditambahkan diatas, serta untuk menyambung ketiga massa dilantai atas, ditambahkan jembatan penghubung yang diisi program agar semua ruang dapat dimanfaatkan secara maksimal. 


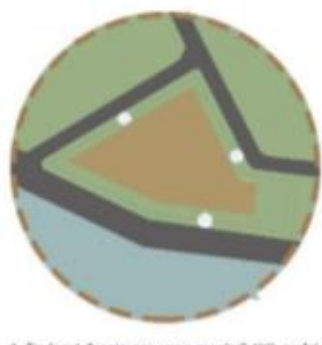

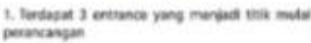

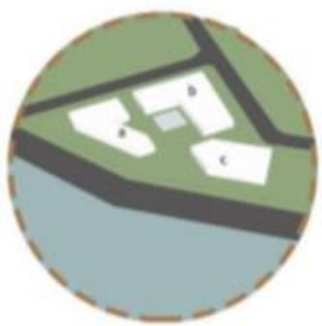

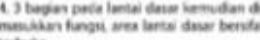

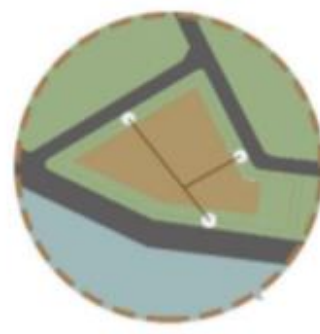

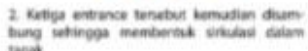

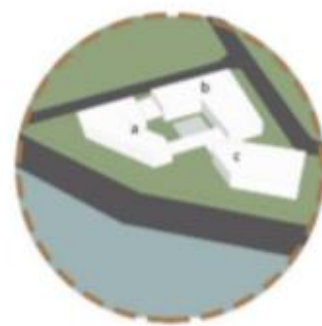

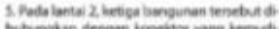

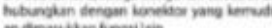

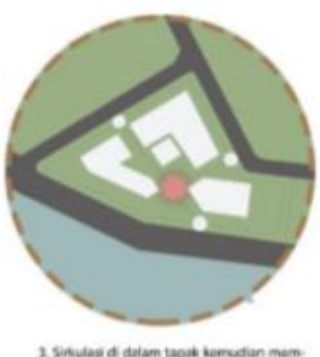

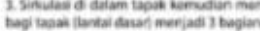

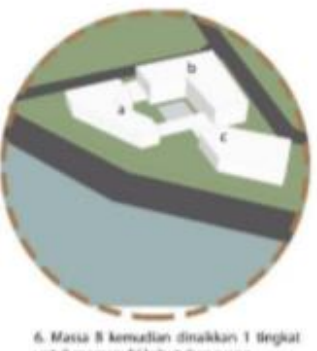

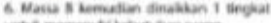

Gambar 6. Gubahan massa \& penempatan program

Sumber:Penulis, 2019

Gubahan massa diatas mementingkan aksesibilitas pedestrian yang merupakan warga kampung disekitar, sehingga sirkulasi antara kendaraan dan pedestrian didalam tapak dipisah dan diatur sedemikian rupa agar tidak terjadi crossing.

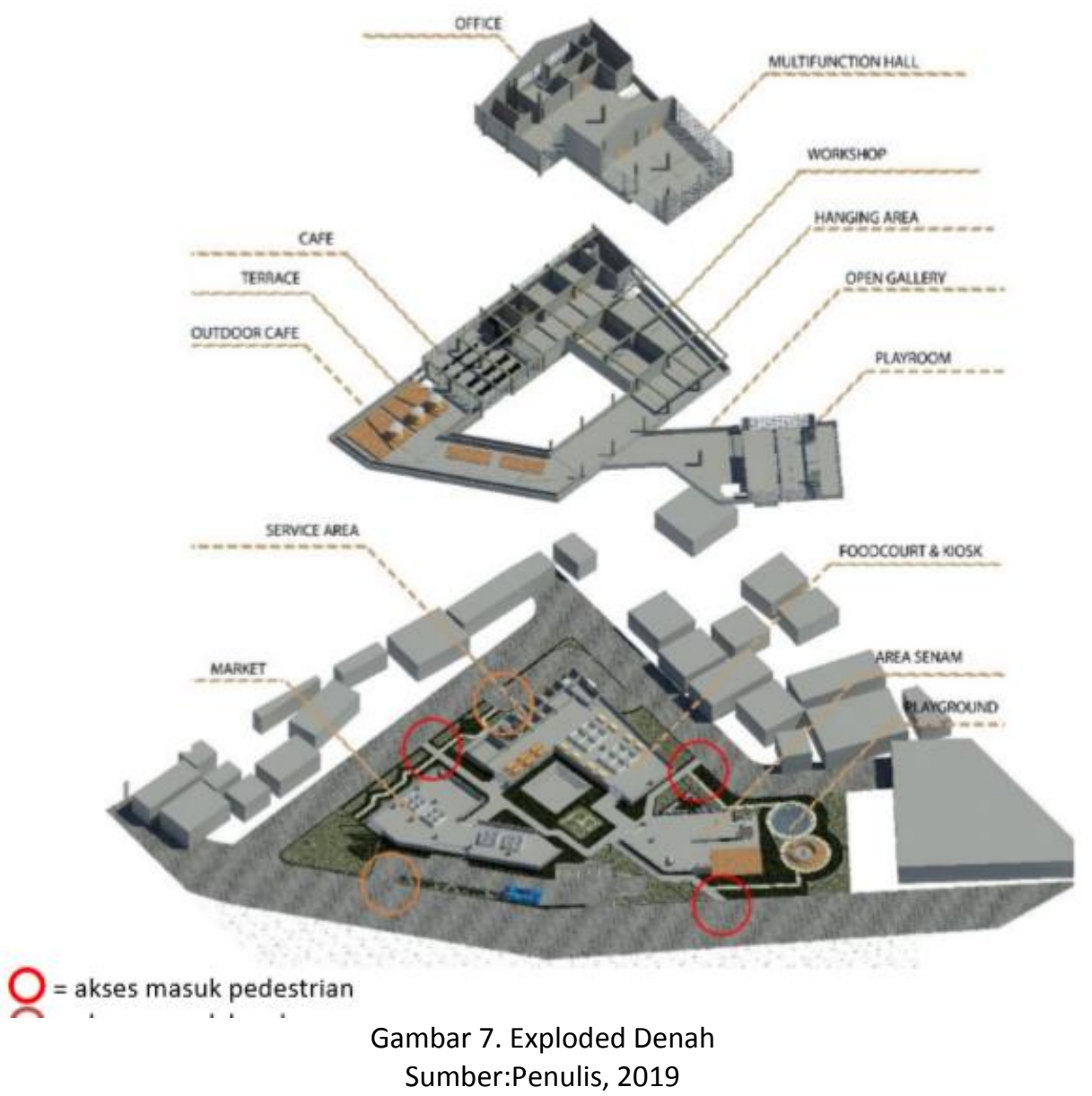


Penempatan program dibedakan menjadi area publik, semi publik dan private, pada lantai dasar. Lantai dasar dapat diakses oleh siapa saja sehingga kegiatan yang dilakukan bersifat terbuka dan komunal. Sedangkan pada lantai 2 (dua) masih terdapat area publik tetapi lebih difokuskan pada area workshop. Sedangkan pada lantai 3 (tiga) hanya dapat diakses oleh orang yang berkepentingan. Pada gambar diatas juga dapat dilihat bahwa bangunan ini memiliki 5 titik entrance, 3 untuk para pedestrian dari ketiga sisi jalan, 1 untuk kendaraan bermotor (pribadi) dan 1 untuk kendaraan bermotot (service). Selain itu, pada lantai 2 diberi jembatan penghubung antara massa 1 dan massa 2 dan memberi kesan ramai. Dan ada area void untuk memberi sirkulasi udara dan cahaya pada area amphitheatre.

\section{KESIMPULAN DAN SARAN}

\section{Kesimpulan}

Manusia sebagai makhluk sosial selalu berinteraksi dengan cara memilih siapa dan apa serta tujuan mereka berinteraksi, sehingga Third place muncul sebagai sebuah tempat yang mewadahi masyarakat untuk melakukan aktivitas seperti bersosialisasi maupun aktivitas lain yang membutuhkan kehadiaran manusia lain. Hal inilah yang mendasari proyek Wadah Aktivitas dan Komunitas Pesisir di Muara Baru ini sebagai sebuah Third place. Bangunan pada proyek ini memiliki 5 program utama yang kemudian dipecah lagi menjadi 2 bagian yaitu programberdasarkan implementasi Third place dimana Third place memiliki konsep netral level, komunikasi adalah hal utama, mudah diakses, memiliki pengunjung tetap, dan suasana yang menyenangkan, sedangkan untuk program yang merupakan tanggapan dari analisis lebih berbentuk mewadahi aktivitas warga setempat. Proyek ini bertujuan untuk menjadi tempat bagi warga setempat untuk berinteraksi dan mewadahi seluruh aktivitas yang tidak dapat dilakukan di rumah (1st place) maupun tempat kerja (2nd place).

\section{Saran}

Lebih mendalam dalam analisis program, agar dapat menghasilkan program yang lebih menarik lagi dan mengolah ruang - ruang kosong agar dapat memaksimalkan pengunjung yang datang

\section{REFERENSI}

Alexander, C. (1964). Notes on the Synthesis of Form. Cambridge: Harvard University Press

Arendt, H. (1958). The Human Condition. Chicago: The University of Chicago Press

Oldenburg, R. (1989).The Great Good Place. U.S. : Paragon House

Tjahjono. G. Metode Perancangan Suatu Pengantar Untuk Arsitek dan Perancang.

Inten Gumilang, 2018, Kampung Muara Baru dan Identitas <https://rujak.org/kampungmuarabaru-dan-identitas/ Steve Jm, 2005, Kebutuhan Ruang Ketiga (Disarikan dari berbagai sumber) <http://jiwangga.com/MyPad/Entries/2005/9/2_Kebutuhan_Ruang_Ketiga.html 